\title{
Em memória de São Tomé: pegadas e promessas a serviço da conversão do gentio (séculos XVI e XVII)
}

\author{
In memory of Saint Thomas: \\ footprints and promises in service of the conversion of \\ the natives (XVI and XVII centuries)
}

Eliane Cristina Deckmann Fleck*

\begin{abstract}
Resumo: Este artigo se propõe a refletir sobre produção discursiva jesuítica dos séculos XVI e XVII, marcada, simultaneamente, pelo desencanto diante da inexistência de evidências de crença religiosa e pelo alento decorrente de notícias de um prévio conhecimento da fé cristã pelos indígenas. Tanto as narrativas epistolares, quanto os sermões e as crônicas produzidas por padres jesuítas revelam a efetiva importância dada ao mito de São Tomé, evocado para justificar a receptividade e o êxito do projeto de civilização e de evangelização promovido pela Companhia de Jesus. A ativação de uma memória sobre a passagem do Apóstolo pela América e a valorização dos seus ensinamentos pelos missionários difundiram - a um só tempo - a crença numa certa predestinação dos jesuítas e de uma predisposição dos nativos americanos ao Cristianismo.
\end{abstract}

Palavras-chave: Escrita jesuítica, Memória, São Tomé

Abstract: This article proposes to reflect about the Jesuitical speech production of the XVI and XVII centuries, marked, simultaneously, by the disenchantment faced with the inexistence of religious belief evidences and by the resulting acknowledgement of news of a prior knowledge of the Christian faith by the native. The epistolary narratives, as well as the the sermons and the chronicles produced by Jesuitical priests, reveal the effective importance given to the myth of Saint Thomas, evoked to justify the receptivity and the success of the project of civilization and of evangelization promoted by the Society of Jesus. The awakening of a memory about the passage of the Apostle through America and the valorization of his teachings by the missionaries diffused - at the same time - the belief in a certain predestination of the Jesuits and in a predisposition of the American natives to Christianity.

Keywords: Jesuitical writings, Memory, Saint Thomas

* Professora do PPGH-UNISINOS, Pesquisadora CNPq-2. E-mail:<edfleck@terra.com.br>. 


\section{Os olhos de muita tinta e papel corrido}

Em sua obra Memória de Ulisses, François Hartog (2004, p. 14-15) ressaltou "que a vista, é de todos os sentidos, o que nos faz adquirir mais conhecimentos e que nos revela mais diferenças." Às narrativas dos que viajam, segundo ele, "prendem-se histórias vindas de alhures ou contadas por eles, receptíveis pela "gente contatada", o que, necessariamente, implica "evocações, retomadas metafóricas e em diversos usos ". ${ }^{1}$ Isso faz com que os olhares não apenas se sucedam, mas também se correspondam, se entrecruzem, ou se sobreponham, marcando o movimento de construção da alteridade. ${ }^{2}$

Assim como os gregos "disseram o Outro", através de suas categorias de heterologia e pensaram a si mesmos, também os viajantes e os missionários dos séculos XVI e XVII se interrogaram e duvidaram de si mesmos, sem deixar, contudo, de atribuir para si "os bons papéis [...] mantendo a posição de mestres do jogo", ${ }^{3}$ selecionando e memorizando "o que há para se ver" (Hartog, 2004, p. 17-27). E por serem eles homens de memória, acabaram por desempenhar também a função de homens de saber, por terem "escrito, preenchido os registros, contado os anos, anotado e arquivado presságios" (Hartog, 2004, p. 63). É preciso, contudo, estar consciente de que "o mesmo olho pode muito bem, de acordo com o momento e o contexto, ver coisas diferentes ou, ao contrário, apresentar como coincidentes traços aparentemente contraditórios" (Hartog, 2004, p. 72), mesmo porque uma história da alteridade implica estarmos atentos ao "seu ritmo, seus tempos fortes e suas rupturas" (Hartog, 1999, p. 37).

De Certeau (1982, p.231), por sua vez, atribui aos homens do século XVI uma "curiosidade enciclopédica" que os faz "amontoa[r] freneticamente", apreender "o raro, o estranho, o singular" no "fervor de uma ambição" para "que tudo se torne servidor dele". Mas, é a escrita que se constitui no elemento decisivo na distinção entre os selvagens e

1 Para De Certeau (1982, p. 212), "a linguagem oral espera para falar, que uma escrita a percorra e saiba o que ela diz. Sobre este espaço de continentes e oceanos oferecidos, antecipadamente, às operações da escrita, se esboçam os itinerários dos viajantes, cujos vestígios vão ressaltar da história".

2 Refletindo sobre o "olhar viajante (do etnólogo)", Sérgio Cardoso afirma que este "remete, de imediato, à atividade e às virtudes do sujeito [...] investiga, indaga a partir e para além do visto [...] deixa aflorar uma certa intenção, trai sempre um certo urdimento, algum cálculo ou malícia - as marcas do artifício sublinham a atuação e poderes do sujeito." (Cardoso In: Novaes, 1988, p. 348)

3 Ampliando esta discussão, Hartog (1999, p. 115) apresenta o discurso do etnólogo como "discurso de verdade: discurso daquele que sabe porque conhece as circunstâncias.” (grifo nosso). 
os ocidentais cristãos, na medida em que "combinando o poder de reter o passado e o de superar indefinidamente a distância [...], faz a história". (De Certeau, 1982, p.217).

Referindo-se aos registros ocidentais sobre os grupos nativos americanos, o antropólogo Miguel Alberto Bartolomé (2006, p. 58) ressalta que estes "apresentam uma série de hiatos de informação, e ao mesmo tempo, uma curiosa continuidade", ${ }^{4}$ na medida em que oferecem "diferentes percepções das estruturas culturais e simbólicas, formadoras do que viria a se constituir na chamada memória coletiva, tanto daqueles que foram registrados, como daqueles que os registraram". Esta memória, segundo o autor, "está sob responsabilidade de alguns personagens reconhecidos socialmente como depositários dos dados capazes de ativarem a memória", o que se dá quando o presente cria uma insatisfação, levando à evocação e valorização do passado.

Para Le Goff (1996, p. 475), a memória tem como propriedade conservar certas informações, que não são ingênuas, mas se fazem e refazem a partir de interesses de grupos, que lutam "pelo poder ou pela vida, pela sobrevivência e pela promoção”. Para Baczko, (1985, p. 309) "todas as épocas têm as suas modalidades específicas de imaginar, reproduzir e renovar o imaginário, assim como possuem modalidades específicas de acreditar, sentir e pensar". Ao referir-se à intervenção ativa sobre a memória coletiva, este mesmo autor afirma que "os acontecimentos contam muitas vezes menos do que as representações a que dão origem e que os enquadram". (Baczko, 1985, p. 310-312).

Detendo-se na relação entre o passado, a memória e o texto, Cinthia Brown, em instigante artigo intitulado Memória e História: a deformação da realidade, recomenda que é preciso dar-se conta da existência de duas temporalidades, ou seja, "o tempo em que se desenrolam os acontecimentos contados e o tempo da redação da narrativa. A memória representa o papel de intermediária entre estas duas temporalidades, pois ela compreende, inicialmente, uma imagem mental do passado [...] mas, em seguida, é aprisionada nas palavras [...] concretiza-se, porém, em diferentes formas de representação. Na medida em que é o escritor que determina essas formas, é ele quem exerce um poder maior ou menor sobre o passado. (apud Tronca In: Bresciani, Naxara, 2001, p. 140) Afinal, o processo de interpretação e de tradução de uma dada realidade é conduzido pelo sujeito que escreve, que ocupa

4 Para De Certeau (1982, p. 217), a escrita está envolvida num "jogo de uma dupla reprodução, uma histórica e ortodoxa que preserva o passado, e outra missionária que conquista o espaço multiplicando os mesmos signos." 
um lugar social e cultural no mundo e que é portador de um saber e de um horizonte de expectativas de sua época. (De Certeau, 1982).

Para Alcir Pécora (In: Luz, 2006, p. 12-13), estudioso da documentação jesuítica, a referência que os escritos de época fazem sobre determinado fato é basicamente uma operação discursiva que mobiliza argumentos ou tópicas duradouras, de eficácias variadas, para lidar com o mundo novo americano ou para lidar com a justificação de suas próprias crenças em relação ao mundo. Isto significa não apenas que, recolhido pelo discurso, o fato não se mantém intacto ou inalterado por ele, mas que o discurso é tão impotente para recolher fatos, quanto potente para inventar mais discursos para lidar ou agir com os fatos. Isto faz com que "Os olhos dos jesuítas que viram o real são antes olhos de muita tinta e papel corrido" [...] e que seus "escritos testemunham predicações de verdade possíveis no âmbito da dogmática jesuítica, com suas variações cabíveis e críveis de aplicação."

Considerando a relevância da discussão sobre a escrita e sobre a representação da alteridade para os estudos coloniais, este artigo se propõe a refletir sobre produção discursiva jesuítica dos séculos XVI e XVII, marcada, simultaneamente, pelo desencanto face à inexistência de religião e pelo alento diante das notícias de um prévio conhecimento da fé cristã pelos indígenas. ${ }^{5}$

\section{Os olhos de Nóbrega e Anchieta e os bons papéis}

No século XVI, ao serem classificados pelos colonizadores como "selvagens", "homens da natureza" e "gente sem história", os indígenas se constituíram em campo aberto para as intervenções civilizadoras ${ }^{6}$.

5 Os registros eclesiásticos referentes à primeira metade do século XVI apontam para esta preocupação, ao informarem sobre as iniciativas feitas para averiguar se os índios tinham conhecimento da Verdade e se já lhes havia sido predicado o Evangelho.

6 Para Hartog (1999, p. 229-231), "Dizer o outro é enunciá-lo como diferente [...] Mas a diferença não se torna interessante senão a partir do momento em que [os dois termos] entram num mesmo sistema. A partir da relação fundamental que a diferença significativa instaura entre os dois conjuntos, pode-se desenvolver uma retórica da alteridade própria das narrativas que falam, sobretudo, do outro [...]". Para traduzir a diferença, um dos recursos à disposição do "viajante" é a "figura cômoda da inversão, em que a alteridade se transcreve como um antipróprio [...] O princípio da inversão é, portanto, uma maneira de transcrever a alteridade, tornando-a fácil de apreender no mundo em que se conta". A descoberta de uma nova humanidade no Novo Mundo, segundo Puntoni (1997, p. 52), fez com que "o processo de construção da alteridade - e de identificação do espaço da barbárie - caminhasse pari passu ao de integração dos novos membros. Afinal, não se dominam povos porque são 'diferentes', mas sim, os tornam 'diferentes' para dominá-los. [...] O projeto evangelizador [...] pretendia inserir esta nova humanidade "na economia divina, o que implica inseri-la na genealogia dos povos'." 
Preocupados em narrar com pormenores os progressos da evangelização, os jesuítas pouco se preocuparam em descrever as crenças indígenas, identificando apenas Tupã como uma espécie de deus. Ao afirmarem que os índios não tinham religião, os missionários reforçavam sua percepção - e convicção - de que assim eles estariam ainda mais capacitados a receber a que lhes ofereciam. Vale aqui lembrar a instigante afirmação de François Hartog, em $O$ Espelho de Heródoto, de que "o mundo que se conta encontra-se no mundo em que conta [...] na maneira como texto faz crer [e] que não é tanto a quantidade de informação nova que se deve levar em conta, mas seu tratamento pelo narrador" (Hartog, 1999, p. 372).

Em sua primeira avaliação, após chegar ao Brasil em 1549, o padre Manuel da Nóbrega ${ }^{7}$ negou qualquer indício de religiosidade nos índios: "é gente que nenhum conhecimento tem de Deus, nem idolos, fazem tudo quanto lhe dizem". Em carta deste mesmo ano, ao Padre Simão Rodrigues de Azevedo, ele informa não ter encontrado - no curto espaço de uma semana - palavras religiosas em tupi: "Trabalhei por tirar em sua língua as orações e algumas práticas de Nosso Senhor, e nem posso achar língua que m'o saiba dizer, porque são eles tão brutos que nem vocábulos têm". (Carta I [1549] In: Moreau, 2003, p. 113 [grifo nosso]).

Ao padre Navarro, diz que os índios "nenhum Deus têm certo, $e$ qualquer que lhe digam ser Deus o acreditam". E continua: "Poucas letras bastariam aqui, porque tudo é papel branco, e não há que fazer outra coisa, senão escrever à vontade" (Carta IV [1549] In: Moreau, 2003, p. 113), e "esta gentilidade nenhuma coisa adora, nem conhece a Deus" (Carta VIII [1551] In: Moreau, 2003, p. 113). Mas, em outro momento - revelando consciência em relação aos limites da evangelização - Nóbrega chega a pedir orientação a Simão Rodrigues, pois "como este gentio não adora coisa alguma, não crê em nada, tudo o que lhe dizeis se fica em nada." (Carta XI [1552] In: Moreau, 2003, p. 114 [grifo nosso]).

\footnotetext{
O padre Manuel de Nóbrega chegou à Bahia, em 1549, na comitiva de Tomé de Sousa que veio fundar a cidade de Salvador e implantar o Governo Geral. Na trajetória de Nóbrega se nota a passagem do humanista esperançoso das primeiras cartas, em que chega a exaltar as qualidades dos índios, para o "administrador pragmático" das últimas, em que prefere depreciá-los. (Carneiro da Cunha, 1990) Antes de se tornar um homem desencantado, Nóbrega iniciava suas cartas ressaltando o quanto se sentia grato por ter sido enviado, como se constata nesta dirigida, em 1549, ao Dr. Navarro, seu mestre em Coimbra: "a estas terras do Brasil, para dar princípio ao conhecimento e louvor de seu santo nome nestas regiões" (Carta IV In: Moreau, 2003, p. 113).
} 
Também José de Anchieta ${ }^{8}$ escreve que: "nenhuma criatura adoram por Deus, somente os trovões cuidam que são Deus, mas nem por isso lhes fazem honra alguma, nem comumente têm idolos nem sortes" (Carta XL [1584] [...]) "não têm juramento nem ídolos" (Carta XLI [1585] In: Moreau, 2003, p. 114 [grifo nosso]).

A "página em branco" ou ausência de qualquer crença ou religião foi quase sempre tida como favorável à cristianização. Mais tarde, no entanto, esta percepção se alteraria: "como este gentio não adora coisa alguma, não crê em nada, tudo o que lhe dizeis se fica em nada. " (Carta XI [1552] In: Moreau, 2003, p. 114). Em um determinado momento, revelando consciência dos limites da evangelização, Nóbrega chega a pedir orientação a Simão Rodrigues:

$[\ldots]$ se nos abraçarmos com alguns costumes deste gentio [...] como é cantar cantigas de Nosso Senhor em sua língua pelo seu tom e tanger seus instrumentos de música, que eles em suas festas, quando matam contrários, e quando andam bêbados, e isto para os atrair e deixarem os outros costumes essenciais, [...] e assim pregar-lhes a seu modo em certo tom, andando, passeando e batendo nos peitos, como eles fazem, quando querem persuadir alguma coisa, e dizêla com muita eficácia, e assim tosquiarem-se os meninos da terra, que em casa temos, a seu modo, porque a semelhança é causa de amor, e outros costumes semelhantes a estes?" (Carta XI [1552] In: Moreau, 2003, p. 123 [grifo nosso]).

Na primeira referência que faz a Tupã, Nóbrega relata o encontro que teve com um pajé que dizia ter "nascido Deus [...] e que aquele Deus dos céus era seu amigo e lhe aparecia frequentes vezes nas nuvens, nos trovões e raios" (Nóbrega, 1988, p. 95). Assim, o jesuíta concluiu que "somente aos trovões chama Tupane, que é como quem diz cousa divina. Eassim nós não temos outro vocábulo mais conveniente para os trazer ao conhecimento de Deus, que chamar-lhe pai Tupane" [grifo nosso]. Estes registros, mais do que apontar para uma dinâmica indígena de absorção e reelaboração da mensagem cristã, atestam que o projeto de catequese "exigiu a elaboração de uma linguagem de mediação, uma linguagem simbólica negociada, inteligível dos dois lados do encontro". (Pompa, 2006, p. 123).

8 José de Anchieta nasceu em 1534, nas Canárias e com 14 anos foi estudar em Coimbra - no período áureo do Humanismo. Em 1551, ingressou na Companhia, tendo sido enviado para o Brasil, em 1553, com 20 anos de idade, para atuar junto a Manuel da Nóbrega. Doente, o padre seguiu a recomendação de buscar os ares saudáveis da América, onde permaneceu por mais de 44 anos. Chegando ao Brasil, sua saúde, efetivamente, deu sinais de melhora. Da Bahia, foi enviado a São Vicente. Em 1554, participou da fundação de Piratininga. Foi um escritor prolixo, entre tratados, relatos, cartas, poesias e autos teatrais, produziu uma documentação rica para análise da natureza americana, de seus habitantes e de suas tradições culturais. 
Selecionando o que havia para ver, os missionários aceitaram os desafios da missão entre homens sem religião, atribuindo para si os "bons papéis" e mantendo-se na posição de "mestres do jogo", como proposto por Hartog. Mas para a manutenção dessa condição, era preciso "reunir o mundo que se conta e o mundo em que se conta" e que a tradução da diferença repousasse sobre procedimentos como a comparação e a transposição, capazes de conferir um "efeito de credibilidade" à narrativa. (Hartog, 1999, p. 245-246).

\section{Verdadeira história, falsas memórias e os homens de saber}

Em carta de 1549, Nóbrega escreve: "Sabem do dilúvio de Noé, se bem que não conforme a verdadeira história (Carta IV In: Moreau, 2003, p. 127); pois dizem que todos morreram, exceto uma velha que escapou em uma árvore". Em uma carta posterior, retoma a associação: "Têm memória do dilúvio, porém falsamente porque dizem que cobrindo-se a terra d'água, uma mulher com seu marido, subiram em um pinheiro e, depois, de minguadas as águas, desceram, e destes procederam todos os homens e mulheres." (Carta V In: Moreau, 2003, p. 127; [grifos nossos]).

Também José de Anchieta diz que os índios "têm alguma noticia do dilúvio, mas muito confusa, por lhes ficar de mão em mão dos maiores que contam a história de diversas maneiras". (Carta XXXIX [1584] In: Moreau, 2003, p. 127) Em outra carta, Anchieta volta a referir a prática da transmissão oral entre os indígenas e, ainda, a importância do testemunho: "É coisa sabida e pela boca de todos corre que há certos demônios (Carta VII [1551] In: Moreau, 2003, p. 185), a que os brasis chamam corupira, que cometem aos índios, muitas vezes no mato, dão-lhes açoites, machucam-nos e matam-nos. São testemunhos disto, os nossos irmãos que viram algumas vezes os mortos por eles." (Carta XXXI [1560] In: Moreau, 2003, p. 129 [grifos nossos]). ${ }^{9}$

A suposta inclinação dos indígenas ao Cristianismo aparece com freqüência nas primeiras correspondências, como nesta passagem em que Nóbrega diz: "Os gentios vêm de muito longe para ver-nos, pela fama que temos, e todos mostram grandes desejos" (Carta VIII [1551] In: Moreau, 2003, p. 185) Para o Nóbrega otimista dos primeiros tempos, os índios recebem os padres com familiaridade e confiança, vão às missas, procissões e festas católicas com alegria e espontaneidade, pois "querem

9 É preciso considerar que "Estudar a descrição como um procedimento de uma retórica da alteridade desemboca na questão da crença", pois, afinal, "Como opera o fazer-crer desse discurso que se constrói entre o olho e a orelha?” (Hartog, 1999, p. 270). 
ser como nós"10: "com quantos gentios tenho falado nesta costa, em nenhum achei repugnância ao que lhes dizia. Todos querem e desejam ser cristãos, mas deixar seus maus costumes lhes parece áspero. Vão, contudo, pouco a pouco caindo na Verdade”. (Carta I In: Moreau, 2003, p. 184 - [grifos nossos]).

Por terem informação de que os carijós eram receptivos à pregação e à conversão, os jesuítas fizeram várias entradas em direção ao Sul para contatá-los, uma vez que "o melhor gentio que há nesta costa" é aquele "aos quais foram, há não muitos anos, dois frades castelhanos ensinar-lhes, e tão bem tomaram a doutrina que tinham já casas de recolhimento para mulheres como freiras e outras de homens, como frades. E isso durou muito tempo, até que o demônio levou lá uma nau de salteadores [...]." (Nóbrega, Informações das partes do Brasil, [1549] In: Hue, 2006, p.33-34 - [grifo nosso]). Definia-se, a partir de então, a distinção entre os índios que aceitavam as entradas dos missionários - o melhor gentio - e os que resistiam à pregação do Evangelho - os indomáveis tapuias ${ }^{11}$-, percepção que se tornou recorrente e difundida através da literatura jesuítica. ${ }^{12}$

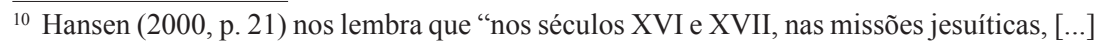
a iniciativa de fazer da pregação oral o instrumento privilegiado de divulgação da Palavra divina pressupunha que a luz natural da Graça inata ilumina a mente dos gentios - objeto da catequese -, tornando-os predispostos à conversão."

11 Segundo Cristina Pompa, (2003, p. 229) "A noção de tapuias constrói-se assim colada à noção de sertão, espaço do imaginário em que a conquista e a colonização vão incorporando aos poucos, em posição subalterna, ao mundo colonial. Ao passo que as aldeias de indios conquistados vão 'descendo' para mais perto da palavra cristã dos missionários, os currais ou os engenhos, os 'Tapuia' vão se afastando, nas serras inacessíveis ou, para usar as palavras de Jaboatão, 'nas brenhas do centro dos sertões'. [grifo nosso]. Puntoni (1997, p. 50), por sua vez, ressalta que “o termo 'Tapuia' não pode ser compreendido como um etnônimo, mas sim como noção historicamente construída. Seu significado básico está associado a uma noção de barbárie duplamente construída. São bárbaros aqueles assim considerados pelos 'Outros' que podem ser integrados mais imediatamente à Cristandade: os Tupi. [...] a integração, ou aceitação abstrata dos Tupi como a humanidade a ser incorporada, implicava na inscrição dos Tapuia como a barbárie."

${ }^{12}$ Cabe ressaltar que o procedimento de tradução classifica, nomeia e impõe "uma grade sobre o espaço divino dos outros, através da qual ele é decifrado e, portanto, construído. A partir de então, basta 'ler' de acordo com o sistema simples de presença-ausência." (Hartog, 1999, p. 260). As implicações desse procedimento foram analisadas por Pedro Puntoni (1997, p. 49) que afirmou: "no caso da história indígena, onde interesse ou desinteresse, preconceitos e comportamentos influíram na definição de etnônimos, das descrições de caráter mais etnográfico ou mesmo especulativo. Por vezes, o desconhecimento ou a redução simplificadora da diversidade encontrada também contribuíram para a imparcialidade das informações. [...] Destaca-se recorrentemente [...] a classificação destes povos em duas unidades culturais (ou mesmo raciais) que funcionam como pólos antagônicos: os Tupi e os Tapuia. Assim, não seria exagero afirmar que este binômio tem sido a chave classificatória fundamental a perpassar a documentação e a historiografia dos cronistas do século XVI até mesmo aos trabalhos coevos." 
Como se pode constatar, os escritos de Nóbrega e Anchieta, além de testemunharem "predicações de verdade possíveis no âmbito da dogmática jesuítica, com suas variações cabíveis e críveis de aplicação", 13 revelam a incorporação de tradições e a rejeição de outras, apontando, ainda, para os seus diversos usos ou para os momentos e contextos mais adequados de sua utilização. ${ }^{14}$ Ambos buscam reinscrever os índios na linhagem cristã - de que teriam se esquecido - para justificar a sua receptividade à doutrina cristã. Uma representação idealizada dos indígenas servirá, em razão disso, para constituir uma imagem dos cristãos como o verdadeiro ideal a ser compreendido e imitado, permitindo "um retorno da Cristandade à Cristandade" (Braga-Pinto, 2003, p.50), condicionado ao abandono das falsas memórias e a comportamentos que expressassem a Vontade indizivel de Deus.

Enquanto homens de saber, os missionários jesuítas acabaram por definir não apenas o que deveria ser tido como verdadeiro ou falso, mas, também, quais as condutas que levariam os indígenas a pouco a pouco cairem na Verdade, a manterem-se nela e a se transformarem na imagem restaurada da piedade cristã." (Braga-Pinto, 2003, p. 76). Assim como o Apóstolo dos primeiros tempos da Cristandade, o jesuíta pregador "estava autorizado a falar porque era um emissário inspirado pelo Espírito Santo, conhecendo as autoridades que deviam necessariamente ser lembradas no ato, segundo os gêneros, a circunstância e as pessoas a quem sua fala era dirigida." (Hansen, 2000, p. 33).

\section{O ver para crer: a evocação do mito de São Tomé}

São Tomé é tido como o apóstolo da descrença ${ }^{15}$, aquele que só depois de tocar nas chagas acreditou ter diante de si o Cristo ressuscitado,

${ }_{13}$ Os registros jesuíticos são, em razão disso, "como um quadro com sua legenda, pois faz-se acompanhar da maneira como convém que sejam "lidos", revelando, conseqüentemente, uma das questões fundamentais para uma retórica da alteridade: "de que fala, no fim das contas, o viajante? Do próprio ou do outro?" (Hartog, 1999, p. 264, 268) "Dizer o outro", afirma o historiador francês, "é muito evidentemente uma forma de falar de nós, se é verdade que a narrativa não pode escapar da polaridade eles/nós, a qual constitui sua armação infrangível. Um dos efeitos do texto, é portanto, contribuir para cercar o nós." (Hartog,, 1999, p. 366).

${ }_{14}$ De acordo com João Adolfo Hansen (1995, p. 101), nas cartas dos jesuítas, a "transferência de convenções narrativas [...] se revela como meio apropriado na 'construção de uma memória de eventos' que, lida na perspectiva da 'similitude', possibilita a projeção, em cada fato novo que é narrado da 'unidade comum da Significação transcendente'."

${ }^{15}$ Dentre as referências mais significativas a Tomé, um dos doze apóstolos de Jesus, é a que se encontra no Novo Testamento, em João 20: 24-29, e que remete para sua incredulidade. 
e que recebeu como justo castigo, a designação para pregar na América, o desafio de "levar a crença aos incapazes de crer ou capazes de crê em tudo." (Viveiros de Castro, 1992, p. 22). Em seu Sermão do Espírito Santo, de 1657, o padre Antônio Vieira discorre sobre as razões do envio de São Tomé "a esta parte da América em que estamos, a que vulgar e indignamente chamaram Brasil”, apresentando-o como punição por sua incredulidade:

E como Santo Tomé, entre todos os apóstolos, foi o mais culpado da incredulidade, por isso lhe coube, na repartição do mundo, a missão do Brasil, porque, onde fora maior a culpa, era justo que fosse mais pesada a penitência. [...] Tomé, que teve a maior culpa, vá pregar aos gentios do Brasil, e pague a dureza de sua incredulidade com ensinar à gente mais bárbara e mais dura. (Vieira [1657], 1957, p. 214-215 [grifo nosso]).

Sua passagem pela América, contudo, entusiasmou os missionários jesuítas do século XVI, povoou a imaginação dos europeus ${ }^{16}$, serviu aos projetos do expansionismo português e espanhol ${ }^{17}$ e se tornou tema de interesse de muitos historiadores, como Sérgio Buarque de Holanda em Visão do Paraíso, publicado em 1959. Refletindo sobre o mito de

\footnotetext{
${ }^{16}$ Segundo Braga-Pinto, “A lenda européia de São Tomé deriva de um longo documento apócrifo do século III ou IV, conhecido como Atos de Tomé ou Actas de S. Tomé, que descreve a viagem do apóstolo à Índia, para onde teria levado o Evangelho e onde foi finalmente martirizado. [...] Os portugueses provavelmente leram sobre a lenda em Marco Polo, entre outras fontes. [...] Por muito tempo, a lenda do Preste João foi associada à história de São Tomé. Durante os séculos XI e XIII eram numerosos os mitos sobre a existência de comunidades cristãs na África e na Índia [...] A importância alcançada por esse mito em Portugal pode ser indicativo da formação de um novo discurso [...] os portugueses procurariam, nos quatro cantos do mundo, outros reinos que já fossem cristãos. Essa identidade prévia com algo remoto produzia - ou confirmava - a imagem de um mundo unificado [...] Além disso, restaurava uma linha temporal definida por uma história que era ao mesmo tempo cristã e universal.” (Braga-Pinto, 2003, p. 37-38)

${ }^{17}$ De acordo com a historiadora portuguesa Maria Lêda Oliveira, da Universidade do Algarve, a lenda do Apóstolo Tomé "esteve intimamente relacionada ao projecto expansionista do reinado de D. Manuel. Com o Venturoso, o mito de S. Tomé incorporou e adquiriu um cariz de estandarte político do Império português, associado á expansão ultramarina para o Oriente e à aliança desejada com os cristãos da terra do Preste João das Índias.” Ainda segundo a autora, "a lenda de S. Tomé não morreria com o fim do reinado de D. Manuel [...] Pelo contrário, continuou viva e servindo de suporte espiritual para alguns projectos políticos da elite letrada lusitana." Contudo, na América espanhola, "o mito foi muito mais relatado", o que fica atestado na "quantidade de escritos dedicados à presença de S. Tomé [...] inclusivamente com testemunhos mais ricamente ornamentados. Talvez, fruto de uma realidade local que necessitava de justificativas mais elaboradas para a empresa de colonização e de expansão da fé. E não fruto apenas da capacidade imaginativa dos espanhóis. [...] A propaganda sistemática dos mitos espirituais servia, portanto, como álibi perfeito para a dura empresa de apropriação definitiva do território.”(Oliveira, 2005, p. 1-3)
} 
São Tomé, Sérgio Buarque de Holanda (1996, p. 108-129) afirmou que: "parece de qualquer modo evidente que muitos pormenores dessa espécie de hagiografia do São Tomé brasileiro se deveram, sobretudo, à colaboração dos missionários católicos, de modo que se incrustaram, afinal, tradições cristãs em crenças originárias dos primitivos moradores da terra." Ele continua, enfatizando que

[...] parece fora de discussão a missionários que identificaram o Sumé brasílico e o Pay Tumé peruano ao discípulo de Jesus na ajuda que teria ele prestado à obra da conversão do gentio. $\mathrm{O}$ próprio Nóbrega já escrevera que, segundo tradição dos índios, lhes anunciara São Tomé, ao partir para a Índia, que "havia de tornar a vê-los". Por sua vez, os missionários jesuítas do Paraguai não hesitaram em interpretar esta promessa como anúncio de seu próprio apostolado. - 'Ide ao mundo inteiro! Pregai o Evangelho a toda criatura'. Mateus, 28,19 - Aos padres Maceta e Cataldino chegara mesmo, certo cacique do Paranapanema, a dizer que Pay Zomé que falara aos antepassados do dia em que toda aquela gentilidade se haveria de estabelecer em povoados por obra de certos homens que levariam a cruz diante de si, o que afinal se realizou com as fundações de Santo Inácio e Loreto [...] (Holanda, 1996, p. 125 [grifo nosso])

Segundo Alfredo Bosi, os jesuítas teriam assimilado e documentado da mitologia indígena apenas os temas que pudessem ser interpretados nos termos da religião cristã, retendo da tradição oral indígena apenas as "entidades cósmicas (Tupã) ou então heróis civilizadores (Sumé), capazes de se identificarem, sob algum aspecto com as figuras pessoais e bíblicas de um Deus Criador ou de seu Filho Salvador" (1992, p. 68). Entretanto, a lembrança do Apóstolo por parte dos índios não teria se expressado de forma tão clara, tendo sido apenas inferida pelos padres, a partir de indícios da sua presença na América. A esse respeito, vale lembrar algumas passagens do Sermão do Espírito Santo do padre Antônio Vieira, que apontam para os limites da pregação do Apóstolo junto aos brasis que, "com a mesma facilidade com que aprendem, desaprendem, e com a mesma facilidade, com que creram, descrêem" 18 :

${ }^{18}$ Esta passagem do Sermão do Espírito Santo remete para o "problema da descrença no século XVI" e para a percepção da "inconstância da alma selvagem", brilhantemente analisados por Eduardo Viveiros de Castros, em artigo intitulado "O mármore e a murta: sobre a inconstância da alma selvagem", publicado em 1992. Após afirmar que "os brasis, ainda depois de crer, são incrédulos" e que "a fé dos brasis: é fé que parece incredulidade, e é incredulidade que parece fé; é fé, porque crêem sem dúvida confessam com repugnância tudo o que lhes ensinam [...]", Antônio Vieira refere a existência de "dois gêneros de estátuas muito diferentes, umas de mármore, outras de murta" nos jardins 
Quando os portugueses descobriram o Brasil, acharam as pegadas de Santo Tomé estampadas em uma pedra [...] mas rastro, nem memória da fé que pregou Santo Tomé, nenhum acharam nos homens. [...] nas gentes não se achou rastro da pregação; as pedras conservaram memórias do apóstolo, os corações não conservaram memória da doutrina. [...] Por que vos parece que passou Santo Tomé tão brevemente pelo Brasil, sendo uma região tão dilatada e umas terras tão vastas? É que receberam os naturais a fé que o santo lhes pregou com tanta facilidade e tão sem resistência nem impedimento, que não foi necessário gastar mais tempo [...] tanto que o santo apóstolo [...] virou as costas, no mesmo ponto se esqueceram os brasis de tudo quanto lhes tinha ensinado, e começaram a descrer ou a não fazer caso de quanto tinham crido [...] na Índia pregou Santo Tomé como fizera às do Brasil [...] chegaram também lá os portugueses e que acharam? Não só acharam a sepultura e as relíquias do santo apóstolo e os instrumentos de seu martírio, mas o seu nome vivo na memória dos naturais, e o que é mais, a fé de Cristo, que lhes pregara, chamando-se cristãos de Santo Tomé todos os que se estendem pela grande costa de Coromandel, onde o santo está sepultado. (Vieira [1657], 1957, p. 215 [grifos nossos]).

Quanto às versões mais antigas do mito, sabe-se que a primeira é de 1516 e se encontra na Nova Gazeta da Terra do Brasil, ${ }^{19}$ de autor anônimo, que informa que naquela "mesma costa ou terra há ainda memória de São Tomé", e que nela há "gente de muito boa e livre condição, gente sem lei, nem rei, a não ser que honram entre si aos velhos [...] e têm recordação de São Tomé [...] Quiseram mostrar aos

das casas dos príncipes. A estátua de mármore, diz ele, "custa muito a fazer, pela dureza e resistência da matéria: mas, depois de feita uma vez, não é necessário que lhe ponham mais a mão: sempre conserva e sustenta a mesma figura; a estátua de murta é mais fácil de formar, pela facilidade com que se dobram os ramos, mas é necessário andar sempre reformando e trabalhando nela, para que se conserve [...] Eis aqui a diferença que há entre umas nações e outras na doutrina da fé. Há umas nações [que] uma vez rendidas, uma vez que receberam a fé, ficam nela firmes e constantes, como estátuas de mármore: não é necessário trabalhar mais com elas. Há outras nações, pelo contrário - e estas são as do Brasil-, que recebem tudo o que lhes ensinam, com grande docilidade e facilidade, sem argumentar, sem replicar, sem duvidar, sem resistir; mas são estátuas de murta que, em levantando a mão e a tesoura o jardineiro, logo perdem a nova figura, e tornam à bruteza antiga e natural, e a ser mato como dantes eram. [...] Eis aqui a razão por que digo que é mais dificultosa de cultivar esta gentilidade, que nenhuma outra do mundo: se os não assistis, perde-se o trabalho, como o perdeu Santo Tomé; e para se aproveitar e lograr o trabalho, há de ser com outro trabalho maior, que é assisti-los; há-se de assistir e insistir sempre com ele, tornando a trabalhar o já trabalhado e a plantar o já plantado, e a ensinar o já ensinado, não levantando jamais a mão da obra, porque sempre está por obrar, ainda depois de obrada." (Vieira [1657], 1957, p. 216 [grifo nosso])

19 Também conhecida como Neue Zeitung aus Brasilien Landt. Ver Anais da Biblioteca Nacional do Rio de Janeiro, v. 23, Rio de Janeiro, 1915, p. 115-118 e 143. 
portugueses as pegadas de São Tomé no interior do país. Indicam também que têm cruzes pela terra adentro. E quando falam de São Tomé, chamam-lhe o Deus pequeno, mas que havia outro Deus maior [...] No país chamam freqüentemente a seus filhos Tomé". O relato continua reforçando uma possível ligação por terra entre o novo continente e a Ásia: "É bem crível que tenham lembrança de São Tomé, pois é sabido que está corporalmente por trás de Malaca; jaz na Costa de Siramath, no golfo de Ceilão". (In: Moreau, 2003, p. 270 [grifo nosso]).

"Para maior certeza da verdade", não poucos procuraram ver "com os próprios olhos" as pegadas que o Apóstolo teria deixado em sua missão evangelizadora ${ }^{20}$ - "coisa que era sabida e pela boca de todos corria" - o que aumentou, ainda mais, a lenda da passagem de São Tomé pela América. Os indícios de sua presença favoreciam não apenas certa identificação dos esforços dos jesuítas com a saga do Apóstolo - que havia pregado em lugares distantes e passado por muitos sofrimentos -, mas os apontavam como sucessores de São Tomé e, por conseqüência, portadores de semelhantes poderes. A difusão da lenda da pregação de São Tomé, no entanto, não foi exclusividade dos jesuítas ${ }^{21}$, apesar de terem sido os que mais buscaram as provas materiais da presença do Apóstolo, chegando a referir a existência de uma profecia que anunciaria a evangelização. ${ }^{22}$

Em carta de abril de 1549, Nóbrega alegou ter visto - com os próprios olhos - as pegadas do Apóstolo: “dizem eles que São Tomé, a

${ }^{20}$ Esta preocupação dos missionários em confirmar "com os próprios olhos" nos remete à afirmação de Hartog de que "Descrever é ver e fazer ver: é dizer o que você viu, tudo o que viu e nada mais do que viu" e que uma "descrição vem a ser também saber e fazer saber". (grifo nosso) Essas descrições - continua o historiador francês - "fazem ver e fazem ver um saber: têm o olho como ponto focal, já que é ele que as organiza (o visível), delimita sua proliferação e as controla (campo visual), bem como as autentifica (testemunha). $\dot{E}$, pois ele que faz crer que se vê e que se sabe, é ele que é produtor de persuasão: eu vi, é verdadeiro."(Hartog, 1999, p. 261-264) [grifo nosso]).

${ }^{21}$ Evidenciando esta não exclusividade temos o registro feito em 1587 pelo provincial da Província de Santo Antonio de Portugal da Ordem dos Frades Menores, Frei Francisco Gonzaga, em seu livro "De origine Seraphicae Ordinis Franciscanae", a propósito da Custódia do Brasil: "porque la tierra esta plantada y fundada, la qual cupo por suerte al bienventurado Sancto Thomas, para ser illustrada, com su predicacion y presencia [...] es tierra muy abundante de açúcar, seda, y de uma raiz que conforme a la tradicion vulgar y comum, fue hallada del Apostol Sancto Thomas antiguamente". (Gonzaga [1587] apud Oliveira, 2005, p. 5). Sabe-se que por volta de 1625, outro franciscano, Frei Sebastião do Rosário, também fez referência à passagem do Apóstolo, ressaltando que havia uma tradição antiga, segundo a qual, S. Tomé havia lhes ensinado a fazer o "mantimento da mandioca".

${ }^{22}$ Cabe aqui referir a obra História do Brasil - 1500-1627, publicada por Frei Vivente do Salvador (1982, p. 112.), em 1630, na qual fez questão de registrar também que era "tradição antiga entre eles que veio o bem-aventurado apóstolo São Tomé a esta Bahia, e lhes deu a planta da mandioca". 
quem chamam Zomé, passou por aqui, isso lhes vem do dito por seus antepassados, e que pegadas dele estão assinaladas à beira de um rio, as quais eu fui ver por ter mais certeza da verdade, e vi com meus próprios olhos quatro pegadas, com seus dedos, mui assinaladas." (Nóbrega, Informações das partes do Brasil [1549] In: Hue, 2006, p. 40 [grifo nosso]). ${ }^{23}$

Nessa mesma carta, o jesuíta conta que São Tomé teria deixado estas pegadas ao fugir dos índios, para a Índia, e que antes disso, teria lhes prometido "que havia de tornar outra vez a vê-los. Ele os veja do céu e seja intercessor por eles a Deus, para que venham a seu conhecimento e recebam a santa fé como esperamos." (Nóbrega, Informações das partes do Brasil [1549] In: Hue, 2006, p. 40 [grifo nosso]).

Escrevendo para o Pe. Simão, Nóbrega informa que teria ouvido de fonte fidedigna que "as raízes de que cá se faz o pão, que S. Thomé as deu, porque cá não tinham pão nenhum [...]. Estão d'aqui perto suas pisadas figuradas em uma rocha, que todos dizem serem suas." (Carta IV In: Moreau, 2003, p. 267 [grifo nosso]).

Ao Pe. Navarro, ele daria mais detalhes: "Têm noticia igualmente de $\mathrm{S}$. Thomé e de um companheiro e mostram certos vestígios em uma rocha, que dizem ser deles, e outros sinais em S. Vicente [...] Dele contam que lhes dera os alimentos que ainda hoje usam, que são raízes e ervas e com isso vivem bem; não obstante dizem mal de seu companheiro, e não sei por que, senão que, como soube, as flechas que contra ele atiravam voltavam sobre si e os matavam". (Carta IV In: Moreau, 2003, p. 267 [grifo nosso]).

Já Anchieta diz que "Lhes ficou dos antigos notícias de uns dois homens que andavam entre eles, um bom e outro mau, ao bom chamavam Çumé, que deve ser o apóstolo S. Tomé, e este dizem que lhes fazia boas obras, mas não se lembram em particular de nada. "Em algumas partes", continua Anchieta, "se acham pegadas de homens impressas em pedra, máxime em São Vicente [...] Estas é possivel que fossem deste Santo Apóstolo e algum discípulo." (Carta XXXIX In: Moreau, 2003, p. 268 [grifo nosso]).

Simão de Vasconcelos teria visto as pegadas em cinco lugares diferentes: ao norte de São Vicente, na Bahia de Todos os Santos, em Itapoã, ao norte dela, em Itajuru, perto de Cabo Frio e no sertão da Paraíba. Frei Jaboatão, por sua vez, os teria encontrado a sete léguas de Recife, enquanto que o historiador da Cia. de Jesus, Nicolas Del Techo, apoiado no testemunho de Nóbrega, referia a existência de um caminho

\footnotetext{
${ }^{23}$ Esta passagem nos remete à reflexão sobre "a dignidade da autópsia" que qualifica uma narrativa, pois, "com efeito, dizer que se viu com os próprios olhos é, ao mesmo tempo, "provar" a verdade: eu o vi, ele é verdadeiro O "eu vi” funciona, em razão disso, "como um operador de crença”. [...]”. (Hartog,, 1999, p. 274-276).
} 
que ligava o Brasil ao Paraguai, o caminho trilhado pelo apóstolo. Assim, também em Assunção, haveria um penedo com pegadas humanas, não descalças, mas de sandálias.

Nos registros deixados pelos padres jesuítas Manuel da Nóbrega e José de Anchieta (século XVI, América portuguesa), e nos de Antônio Ruiz de Montoya (século XVII, América hispânica), constatamos a efetiva importância dada ao mito de São Tomé, tanto para a exposição de inclinações favoráveis e das inaptidões naturais dos indígenas, quanto para a justificativa do êxito do projeto de civilização e de evangelização. A ativação de uma memória ${ }^{24}$ e a valorização dos ensinamentos da figura mitológica São Tomé - ou Pay Zumé - reforçaram - a um só tempo - a crença numa certa predestinação dos jesuítas e de uma predisposição dos indígenas ao Cristianismo.

\title{
Haciendo memória de las cosas ${ }^{25}$ : do poder de restituir a vida e da veneração à memória de São Tomé e de Montoya no Paraguai
}

\author{
O padre jesuíta Antônio Ruiz de Montoya ${ }^{26}$ produziu - supostamente \\ em 1617 - uma Relación (manuscrita) sobre el Apóstolo Santo Tomás,
}

\footnotetext{
${ }^{24}$ Vale lembrar que no "Novo Testamento, a salvação se materializa na lembrança de Jesus: 'E tomando o pão, deu graças, partiu e deu a eles dizendo: 'Isto é o meu corpo, que será entregue por vós. Fazei isto em minha memória'”. (Lucas, 22:19).

${ }^{25}$ É importante destacar que para os membros da Companhia de Jesus, a memória "se configurava enquanto uma das exigências institucionais para 'ajuda das almas'. As Constituições da Companhia de Jesus exigiam do candidato à Companhia que além das faculdades da inteligência e da vontade fosse incluída a memória como 'a capacidade de aprender e fidelidade para reter o que se aprende'. [...] Ademais, ao referir o uso da memória por um padre jesuíta no século XVI, deve-se considerar que o cristianismo, assim como o judaísmo, fundamenta-se na memória e na recordação [...]" (Vilar, 2006, p. 176. Além disso, como bem lembrado por Fernando Torres Londoño, "A Companhia de Jesus nasceu e se estendeu, no século XVI, a quatro continentes sob o domínio da escrita. No momento em que a primeira dúzia de 'companheiros' se colocou a serviço do papa, compreendeu-se que a dispersão poderia ameaçar sua união e para se manterem unidos em Jesus Cristo nasceu o Instituto. Importava assim, neste momento, estabelecer os canais e formas de comunicação da Companhia, das corriqueiras às mais complexas, como a que passava pela convocação da Congregação Geral. Interessava, em particular, cuidar da circulação de informações pessoalmente ou por 'letras'. [...] Quando os padres e irmãos começaram a se comunicar por cartas desde as mais variadas partes do globo, este espírito inundava sua escrita [...]. Ao escrever sobre sua missão, os jesuitas of faziam utilizando um registro ou tom inspirado na subjetividade de sua vivência do carisma inaciano". (Londoño, 2002, p. 13; [grifo nosso]).

${ }^{26}$ Montoya nasceu a 13 de junho de 1585, na cidade de Lima, Peru. Orfão de pai e mãe, ele chegou a freqüentar a Real Escuela de San Martin. Adolescente, abandonaria os estudos, dedicando-se à vida cortesã. Estimulado pelo Padre Gonzalo Suarez entraria no noviciado em 1606, após onze meses de estudos preparatórios. É ordenado padre pelo Bispo Trejo y Sanabria, em Santiago Del Estero, em 02 de março de 1611. Em setembro do mesmo ano, chegaria a Assunção, onde esperou seis meses para seguir até o Guairá, onde daria início à atividade apostólica.
} 
que viria a ser transcrita, em 1755, pelo Padre Lozano, em sua obra Historia de la Compañía de Jesus en la Província del Paraguay. Nela encontramos a seguinte informação: "Conservam os bárbaros tão fresca a memória de São Tomé e de seus prodígios, como se eles mesmos o tivesses visto e conhecido. Os índios traziam defuntos para que os missionários os restituíssem a vida, porque assim diziam havia feito Pay Zumé para provar que era a Palavra de Deus que ele predicava." (apud Lozano, 1755, p. 719).

Dez anos depois, Montoya voltaria a fazer referência a São Tomé em uma carta que integraria a Décima Segunda Carta Ânua que seria assinada pelo Provincial da Província Jesuítica do Paraguai, Padre Nicolás Mastrilli Durán:

[...] a princípio dei pouco crédito a uma profecia que me contavam os índios: a de que o Santo havia profetizado a nossa vinda a estas partes. Como isto foi ouvido em distintas nações e tão distantes umas das outras, de maneira alguma pode haver suspeita de haverem se comunicado os índios entre si a ponto de concordar em tantos aspectos e não haver discrepâncias. Me parece oportuno aqui referir-la porque a ouvi de novo entre os índios desta nação. Tem eles por tradição - que se tem passado de pais para filhos - que em tempos futuros chegariam a suas terras uns padres que lhes ensinariam a Palavra de Deus, os juntariam e grandes povoados, lhes fariam viver em ordem e observando os principios cristãos, ensinando-lhes a amar uns aos outros e orientando-os a não terem mais de uma mulher. Recordam eles aquilo que ouviram de seus avós sobre as promessas feitas por Santo Sumé ou Tomé. (MCA I, 1951, p. 274 [grifos nossos]).

Em 1628, ele voltaria a se referir ao "glorioso apóstolo Santo Tomás" em um texto que foi transcrito e publicado pelo P. Francisco Jarque (1900, p. 230, [grifo nosso]), e no qual afirmava: "Vimos, meus companheiros e eu, um caminho [...] que corre por toda aquela terra e me tem certificado alguns portugueses que vem do Brasil, que este caminho é o de São Tomé."

No mesmo ano, ao informar sobre a situação da missão jesuítica instalada no Guairá, o Padre Montoya escreveu em:

[...] com algum receio pego a pena para escrever algo que aconteceu nestas reduções do Guairá porque haciendo memória de las cosas percebo que não faltaram sinais para que em tudo sigamos o Apóstolo São Tomé que abriu caminhos incógnitos e inusitados, rompendo montes e deixando na terra movediça impressas as suas pisadas para que servissem de guia aos próximos provinciais e de mostradores do caminho. (MCA I, 1952, p. 259-298 [Grifos nossos]). 
No capítulo X - Ritos dos índios Guaranis -, da sua obra Conquista Espiritual, de 1639, ${ }^{27}$ Antônio Ruiz de Montoya (1985, p.53) faz a primeira referência a São Tomé: "Tenho para mim que somente lhes sobrou a pregação do apóstolo São Tomé, que, como veremos, anunciou os mistérios divinos." Na sequência, nos capítulos XXI a XXVI ele apresenta sua interpretação sobre a passagem de São Tomé: "Estranhando nós um acolhimento tão fora do comum, disseram-nos que por tradição antiqüíssima e recebida de seus antepassados, por São Tomé - a quem comumente chamam 'Pay Zumé na Província do Paraguai e 'Pay Tumé nas do Peru - este lhes havia dito que a doutrina que pregava, se perderia com o tempo e, que depois de muito tempo, viriam uns sacerdotes trazendo cruzes e que os seus descendentes ouviriam esta mesma doutrina." Montoya (1985, p. 87) concluiu que "obrigou-os essa tradição a dar-nos acolhida tão extraordinária." Segundo ele, "Existe a tradição entre os índios de que o Santo Apóstolo pregava aos gentios do alto daquela rocha e que, ao ouvi-los se enchiam de gente aqueles campos. E que segundo a tradição existente no Paraguai 'quando o mar atingir a esta pedra, por divina disposição hão de vir homens brancos de terras muito remotas, para pregarem a doutrina que eu agora vos ensino e para renovarem a memória de mesma '." (Montoya, 1985, p. 96 [grifos nossos]).

Esta menção - feita por Montoya - à necessidade de constantemente renovarem a memória da tradição mítica parece ter sido seguida à risca pelos missionários jesuítas, empenhados numa conversão que se fez com pegadas, promessas e curas. À página 101 de sua obra Conquista Espiritual, o padre Montoya (1985, p.101, [grifo nosso]) faria uma curiosa recomendação, antevendo, de certa forma, a importância que os historiadores dariam ao mito de São Tomé: "Com isso concluí o assunto relativo à cruz, aos rastros e vestígios que existem no ocidente quanto ao glorioso Apóstolo. Voltar-me-ei agora às minhas reduções e faço-o

${ }^{27}$ Para Maria Cristina dos Santos (2002, p. 217), é "no contexto das discussões da época que deve-se compreender os capítulos que Ruiz de Montoya dedica à passagem do apóstolo Santo Tomás, e as referências que utiliza para evidenciar um conhecimento prévio dos indígenas do Evangelho. Havia um consenso geral de que os povos indígenas inquestionavelmente descendiam de Adão e, como o Dilúvio havia sido universal; conseqüentemente pertenciam à linhagem de Noé. A polêmica se introduzia no momento de decidir quando caíram na idolatria, posto que existiam indícios para pensar que haviam tido o conhecimento de Deus antes da chegada dos espanhóis; tal circunstância somente podia se explicar ou bem porque os índios conservaram durante algum tempo o legado dos filhos de Noé ou porque um dos apóstolos, seguindo o mandado de Jesus, chegou a predicar nestas terras." 
desejoso de que alguém (um dia) tome este rascunho, para tratar desta história com (mais) fundamento."

Mais do que ver atendido o desejo de que - com mais fundamento - os seus rascunhos sobre São Tomé fossem retomados, Antônio Ruiz de Montoya foi - ele próprio - alvo de uma memória. Na Carta Ânua da Província Jesuítica do Paraguai, referente aos anos de 1659-1662, encontramos os seguinte relato do Provincial Andrés de Rada:

[...] pois se cobriram as tampas do ataúde do apostólico Padre Antonio Ruiz de Montoya de um copioso suor que parecia indicar os grandes sofrimentos e humilhações pelas quais tiveram que passar os nossos padres junto à missão entre os calchaquís, ocasião em que foram vergonhosamente e injustamente expulsos de sua morada. Os primeiros da Província do Guairá convertidos pelo padre Antônio Ruiz de Montoya foram precisamente os habitantes do povoado de Loreto. Por isto, eles guardam os restos daquele padre em sua Igreja, como um tesouro de inestimável preço. A memória daquele Padre encontra tanta veneração entre eles, que a ele fazem pedidos e promessas com bons resultados. Assim que havendo esta crença bem fundada, três enfermos do povoado, já desenganados, recobraram a saúde por intercessão do padre Antônio. (Apud Leonhardt, 1927, p. 28 [grifo nosso]). ${ }^{28}$

Este relato nos revela que em torno de Montoya, assim como já ocorrido com São Tomé, funda-se uma memória que se assenta sobre promessas e a restituição à vida daqueles que a ele foram enviados. Ao ser acionada por missionários e indígenas, a memória de Montoya parece evocar uma retomada metafórica do mito de São Tomé, justificando o muito papel e a muita tinta já utilizados para a sua difusão. ${ }^{29}$

${ }^{28}$ Segundo Gloria Kok (2008, p. 6; [grifo nosso]), "Enquanto os ossos dos xamãs eram cultuados longe da esfera de visibilidade dos jesuítas, a religião católica estimulava o culto ás relíquias, representativo da expansão do Cristianismo no Novo Mundo. Assim, os ossos dos mártires da catequese foram cultuados oficialmente, mas não exatamente à moda européia, desnudando, nesses interstícios, o processo de interação simbólica no contexto da colonização." Nesta perspectiva, a adoração dos ossos do jesuíta, "alude, do ponto de vista cristão, à configuração de uma nova geografia espiritual no âmbito colonial, em torno da qual se constrói a identidade cristã. [...] Da perspectiva tupi, entretanto, os ossos dos jesuítas, numa operação de transferência simbólica, suscitam a memória dos ossos dos xamãs".

${ }^{29}$ Para Viveiros de Castro (2002, p. 218), os empréstimos cristãos revelam a propensão da sociedade indígena de "se ver como Outro", isto é de assimilar os signos de alteridade. (Viveiros de Castro, Gruzinski, (2003, p. 305) por sua vez, defende que a apropriação dos símbolos cristãos representava uma incorporação sem que a estrutura simbólica indígena fosse desfeita. 


\section{Referências}

BACZKO, Bronislaw. Imaginação social. In: Enciclopédia Einaudi. Lisboa: Imprensa Nacional-Casa da Moeda, 1985. v. 5, p. 296-332.

BARTOLOMÉ, Miguel Alberto. Procesos interculturales: Antropología política del pluralismo cultural en América Latina. México: Siglo XXI, 2006.

BRAGA-PINTO, César. As promessas da História. Discursos proféticos e assimilação no Brasil colonial (1500-1700). São Paulo: EDUSP, 2003.

CARDOSO, Sérgio. O olhar viajante (do etnólogo). In: NOVAES, Adauto. (Org.). O olhar. São Paulo: Companhia das Letras, 1988. p. 347-360.

DE CERTEAU, Michel. A escrita da História. Rio de janeiro: Forense Universitária, 1982.

HARTOG, François. $O$ espelho de Heródoto: ensaio sobre a representação do outro. Belo Horizonte: UFMG, 1999.

HARTOG, François. Memória de Ulisses: narrativas sobre a fronteira na. Grécia antiga. Tradução de Jacyntho Lins Brandão. Belo Horizonte: UFMG, 2004.

GRUZINSKI, Serge. A colonização do imaginário. Sociedades indígenas e ocidentalização no México espanhol. Séculos XVI-XVIII. São Paulo: Companhia das Letras, 2003.

HANSEN, João Adolfo. O nu e a luz: cartas jesuíticas do Brasil. Nóbrega - 1549-1558. Revista do IEB, São Paulo, n. 38, p. 87-119, 1995.

HANSEN, João Adolfo. A civilização pela palavra. In: LOPES, Eliane; FARIA FILHO, Luciano; VEIGA, Cynthia. (Orgs.). 500 anos de educação no Brasil. Belo Horizonte: Autêntica, 2000. p. 19-41.

HOLANDA, Sérgio Buarque de. Visão do Paraíso. Os motivos edênicos no descobrimento e colonização do Brasil. São Paulo, Brasiliense, 1996.

HUE, Sheila Moura. (Introdução e Notas). Primeiras Cartas do Brasil. Rio de Janeiro: Jorge Zahar Editor, 2006.

JARQUE, Francisco. Ruiz de Montoya en Indias (1608-1652). Madrid: Victoriano Suárez, 1900. 4 t.

KOK, Glória. Memória dos Ossos: Xamãs e Jesuítas em processo de interação simbólica e resistência na América Meridional (séculos XVI e XVII). [CD-R]. Anais do XIX Encontro Regional de História - ANPUH/SP, 2008.

LE GOFF, Jacques. História e Memória. Campinas, SP: Editora da UNICAMP, 1996.

LEONHARDT, Carlos. Cartas Ânuas de la Província Jesuítica del Paraguay. Buenos Aires, 1927. (mimeo inédito)

LONDOÑO, Fernando Torres. Escrevendo cartas. Jesuítas, escrita e missão no século XVI. Revista Brasileira de História, São Paulo, v. 22, n. 43, p. 11-32, 2002.

LOZANO, Pedro. Historia de la Compañia de Jesús en la Provincia del Paraguay, Madrid: Imprenta de la viuda de M. Fernández, 1755. (ed. fac-similar)

LUZ, Guilherme Amaral. Carne humana: canibalismo e retórica jesuítica na América portuguesa (1549-1587). Uberlândia: EDUFU, 2006.

MANUSCRITOS DA COLEÇÃO DE ANGELIS (MCA).Vol. I: Jesuítas e Bandeirantes no Guairá (1549-1640). Introdução e notas por Jaime Cortesão. Rio de Janeiro: Biblioteca Nacional, 1951. 
MONTOYA, Antônio Ruiz de. Conquista Espiritual. Porto Alegre: Martins Livreiro, 1985.

MOREAU, Filipe Eduardo. Os Índios nas Cartas de Nóbrega e Anchieta. São Paulo: Annablume, 2003.

NÓBREGA, Manuel da. Cartas do Brasil. Belo Horizonte. São Paulo: Itatiaia/EDUSP, 1988.

NOVAES, Adauto. O olhar. São Paulo: Companhia das Letras, 1988.

OLIVEIRA, Maria Lêda. O Apóstolo S. Tomé, o império português e o lugar do Brasil. [CD-R] Actas do Congresso Internacional Espaço Atlântico de Antigo Regime: poderes e sociedades. Lisboa, 2005.

POMPA, Cristina. Religião como tradução. Missionários, Tupi e Tapuia no Brasil colonial. Bauru, SP: EDUSC, 2003.

POMPA, Cristina. Por uma antropologia histórica das missões. In: MONTERO, Paula (Org.). Deus na Aldeia. Missionários, índios e mediação cultural. São Paulo, Globo, 2006. p. 111-142.

PUNTONI, Pedro. Tupi ou não Tupi? Uma contribuição ao estudo da etnohistória dos povos indígenas no Brasil Colônia. In: RISÉRIO, Antônio. Invenção do Brasil. Salvador: MADE, 1997. p. 49-55.

SALVADOR, Frei Vivente do. História do Brasil: 1500-1627. 7. ed. Belo Horizonte: Itatiaia; São Paulo: EDUSP, 1982.

SANTOS, Maria Cristina dos. Crença e descrença na América Meridional do século XVII. In: DREHER, Martin. (Org.). 500 anos de Brasil e Igreja na América Meridional. Porto Alegre: EST Edições, 2002. p. 215-222.

TRONCA, Ítalo. Foucault, a Doença e a Linguagem delirante da Memória. In: BRESCIANI, Stella, NAXARA Márcia (Orgs.). Memória (res)sentimento. Indagações sobre uma questão sensivel. Campinas, SP: Editora da Unicamp, 2001. p. 129-148.

VIEIRA, Antônio. Sermões. São Paulo: Editora das Américas, 1957.

VILAR, Socorro de Fátima Pacífico. A invenção de uma escrita: Anchieta, os Jesuítas e suas Histórias. Porto Alegre: EDIPUCRS, 2006.

VIVEIROS DE CASTRO, Eduardo. O mármore e a murta: sobre a inconstância da alma selvagem. Revista de Antropologia, São Paulo, n. 35, p. 21-74, 1992.

VIVEIROS DE CASTRO, Eduardo. A inconstância da alma selvagem e outros ensaios antropológicos. São Paulo: Cosac\&Naify, 2002. 